\title{
Impact of climate change on the water resources of the eastern Mediterranean and Middle East region: Modeled 21st century changes and implications
}

\author{
Jonathan Chenoweth, ${ }^{1}$ Panos Hadjinicolaou, ${ }^{2}$ Adriana Bruggeman, ${ }^{2}$ Jos Lelieveld, ${ }^{2,3,4}$ Zev Levin, ${ }^{2,5}$ \\ Manfred A. Lange, ${ }^{2}$ Elena Xoplaki, ${ }^{2,6}$ and Michalis Hadjikakou ${ }^{1}$ \\ Received 23 November 2010; revised 17 March 2011; accepted 25 March 2011; published 10 June 2011.
}

[1] The likely effects of climate change on the water resources of the eastern Mediterranean and Middle East region are investigated using a high-resolution regional climate model (PRECIS) by comparing precipitation simulations of 2040-2069 and 20702099 with 1961-1990. The simulations show about a 10\% decline in precipitation across the region by both the middle and the end of the century, with considerable variation between countries and international river basins. Results suggest that per capita water resources will not change particularly significantly in southeastern Europe, where they are relatively plentiful and population growth is minimal. However, in much of the Middle East, climate change coupled with population growth is likely to reduce per capita water resources considerably. This will inevitably result in major social, economic, and environmental change in the region. Countries where the required adaptation is likely to be particularly challenging include Turkey and Syria because of the large agricultural workforces, Iraq because of the magnitude of the change and its downstream location, and Jordan because of its meager per capita water resources coupled with limited options for desalination. If the internal water footprint of the region declines in line with precipitation but the total water footprint of the region increases in line with population, then by midcentury, as much as half the total water needs of the region may need to be provided through desalination and imported in the form of virtual water.

Citation: Chenoweth, J., P. Hadjinicolaou, A. Bruggeman, J. Lelieveld, Z. Levin, M. A. Lange, E. Xoplaki, and M. Hadjikakou (2011), Impact of climate change on the water resources of the eastern Mediterranean and Middle East region: Modeled 21st century changes and implications, Water Resour. Res., 47, W06506, doi:10.1029/2010WR010269.

\section{Introduction}

[2] Climate change is making itself felt in the eastern Mediterranean region [Plan Bleu, 2009]. The region is notorious for water stress and water scarcity as ever greater demands are placed on limited water resources through population growth and economic development [Allan, 2001]. Geographical gradients are large, however, as mean precipitation across the region varies from less than $100 \mathrm{~mm}$ $\mathrm{yr}^{-1}$ in Bahrain and Qatar to more than $1000 \mathrm{~mm} \mathrm{yr}^{-1}$ in Albania, Bosnia and Herzegovina, and Georgia (Food and Agriculture Organization (FAO), AQUASTAT: FAO's information system on water and agriculture, available at http://www.fao.org/nr/water/aquastat/main/index.stm, hereinafter referred to as FAO, AQUASTAT, 2009). Precipita-

\footnotetext{
${ }^{1}$ Centre for Environmental Strategy, University of Surrey, Guildford, UK ${ }^{2}$ Energy, Environment and Water Research Center, Cyprus Institute, Nicosia, Cyprus.

${ }^{3}$ Max Planck Institute for Chemistry, Mainz, Germany.

${ }^{4}$ College of Science, King Saud University, Riyadh, Saudi Arabia.

${ }^{5}$ Department of Geophysics and Planetary Science, Tel Aviv University, Tel Aviv, Israel.

${ }^{6}$ Institute of Geography, University of Bern, Bern, Switzerland.
}

Copyright 2011 by the American Geophysical Union. 0043-1397/11/2010WR010269 tion is thus generally low and has high spatial and temporal variability.

[3] The Middle East is the first region of the world to effectively run out of water [Allan, 2001]. The rapidly growing nonagricultural water needs of many countries in the area can generally not be met by further exploitation of water resources except through either the development of expensive desalination facilities or the reallocation of water resources from agriculture. This could bring major social and political change and risk exacerbating existing inequalities and regional tensions.

[4] Climate change is expected to bring further challenges to the task of ensuring an adequate water supply for social and economic development as changes in precipitation patterns and temperature risk reversing development gains of recent decades. By anticipating the nature and magnitude of the changes to water resources that climate change is likely to bring, the expected consequences of these changes can be foreseen, and adaptive measures may be able to be identified and put in place. While there has been some research on climate change and water resources in the eastern Mediterranean and Middle East (EMME) region, none examines water resources on a national basis for the whole region in the middle and the end of the $21 \mathrm{st}$ century using a high-resolution model. Krichak et al. 
[2007] cover the eastern Mediterranean region, but their model domain was more limited geographically, its resolution was relatively course (50 $\mathrm{km}$ grid), and they only covered the 2071-2100 period. Giorgi and Lionello [2008] review data from a range of models covering a range of time periods with various resolutions. The high-resolution (20 km grid) model results they reviewed, however, covered only the 2071-2100 period, and while they included the eastern Mediterranean region in their study, they did not cover the majority of the Middle East. Kitoh et al. [2008] and Önol and Semazzi [2009] only cover the end of the 21 st century, while Hemming et al. [2010] only cover the 2021-2050 period in the Middle East but not elsewhere in the eastern Mediterranean. This paper examines what the likely effects of climate change on the annual renewable water resources of the EMME region are over the 21 st century using a high-resolution regional climate model (PRECIS) and then seeks to identify the potential implications of these effects on water management in this already water-stressed region. Changes in interannual variability or seasonal distribution of precipitation are not examined in this paper.

[5] Climate change impacts upon whole societies and will thus require adaptation measures to be undertaken at a national or regional level. Water resources, in particular, are frequently managed on a national basis, while cross-border river basins additionally require international cooperation. This national or regional basis for water management means that the analysis that follows will only consider countries that are wholly encompassed by the modeled area and that do not receive significant cross-boundary water inflows from any transnational rivers originating outside the modeled area. Thus, Egypt, which is only partially covered by the modeled area and which receives approximately $97 \%$ of its water resources as a cross-boundary flow from the Nile River (FAO, AQUASTAT, 2009), which originates outside the modeled area, is not included. Similarly, Iran, which is only partially covered by the modeled area, is not included, but western Iran, which encompasses some of the headwaters of the Tigris River, is included, thus allowing the consideration of the water resources of Iraq, whose river basin headwaters are wholly within the modeled area.

[6] Figure 1 shows the modeled area and the countries that are the focus of this paper: Albania, Armenia, Azerbaijan, Bahrain, Bulgaria, Cyprus, the former Yugoslav Republic of Macedonia (FYROM), Georgia, Greece, Iraq, Israel, Jordan, Kuwait, Lebanon, the Palestinian territories (the West Bank and Gaza Strip), Qatar, Syria, and Turkey. The paper is organized in five sections. In section 2 the available data sources used in this research are presented, followed in section 3 by an outline of the applied methodology. Section 4, which presents the results, is divided into the area analysis as a whole and the analysis of the individual countries, including the physical and the socioeconomic factors influencing the water resources. Finally, the paper is concluded in section 5 with an assessment of the usability of our results for policy makers in the area.

\section{Data and Projections}

[7] Water resources data have been taken from the AQUASTAT database (FAO, AQUASTAT, 2009) and
CRU CL 2.0 [New et al., 2002] of the Climate Research Unit at the University of East Anglia. AQUASTAT data refer to long-term averages of different periods in the 20th century, on a country by country basis, that come from multiple sources, such as national sources, including country surveys carried out as part of the AQUASTAT program. Thus, for example, the AQUASTAT precipitation estimate for Jordan refers to the period for 1937/1938 to 2005/2006, but for most countries this data set refers to the 1961-1990 period. CRU CL 2.0 is a 10 arc min global gridded data set interpolated from 27,075 data stations for the period 19611990 [New et al., 2002]. Table 1 presents basic socioeconomic and water resources data for the study countries, including annual precipitation depth, internal water resources, and percentage of available water resources used.

[8] Water resources are sometimes categorized into blue and green water. Blue water refers to water that can be extracted from the environment and thus includes surface and groundwater. Green water refers to soil water resulting from precipitation, which can be used in situ by plants and returned to the atmosphere via evapotranspiration, and thus is the difference between the volume of precipitation and the blue water generated within a given area [Falkenmark, 1995]. Internal water resources refer to the blue water resources that are generated entirely within the boundaries of a country, thus being determined by the land area of the country and precipitation and evapotranspiration rates. Total water resources of a country, however, also take into consideration cross-boundary flows, with such flows in some cases significantly increasing or decreasing the total available blue water resources. In the case of Turkey, for example, internal water resources are currently estimated to be $227.0 \mathrm{~km}^{3} / \mathrm{yr}$, but total water resources are $173.8 \mathrm{~km}^{3}$, primarily because of the outflow of water down the Tigris and Euphrates rivers (FAO, AQUASTAT, 2009). This paper focuses upon changes in precipitation across the study region because precipitation determines the total amount of water (both green and blue) generated within a country from natural sources and therefore is potentially available for agricultural, industrial, or domestic use. In addition, this paper also considers internal water resources (thus considering the blue water generated within a country) as this is the amount of water extractable from the environment that can be distributed by a country among different sectors. In contrast, green water can only be used in situ for agriculture.

[9] Obtaining accurate data on natural river discharges of international river basins in the Middle East region is very challenging. In part this is due to the nonrelease of data by individual countries, but it is also due to extensive water withdrawals from the region's rivers going back decades or, in some locations, millennia. This means that current river discharge observations are not representative of the natural river discharge. While there are several significant transboundary river basins in the EMME region, because of data availability limitations, just two of the more significant basins will be evaluated here: the TigrisEuphrates river basin and the Jordan River basin. Both of these river basins provide a significant proportion of the total available water resources for certain countries in the region, and although discharge rates are not necessarily great by global standards, significant changes in their average discharge rates due to climate change could have a 


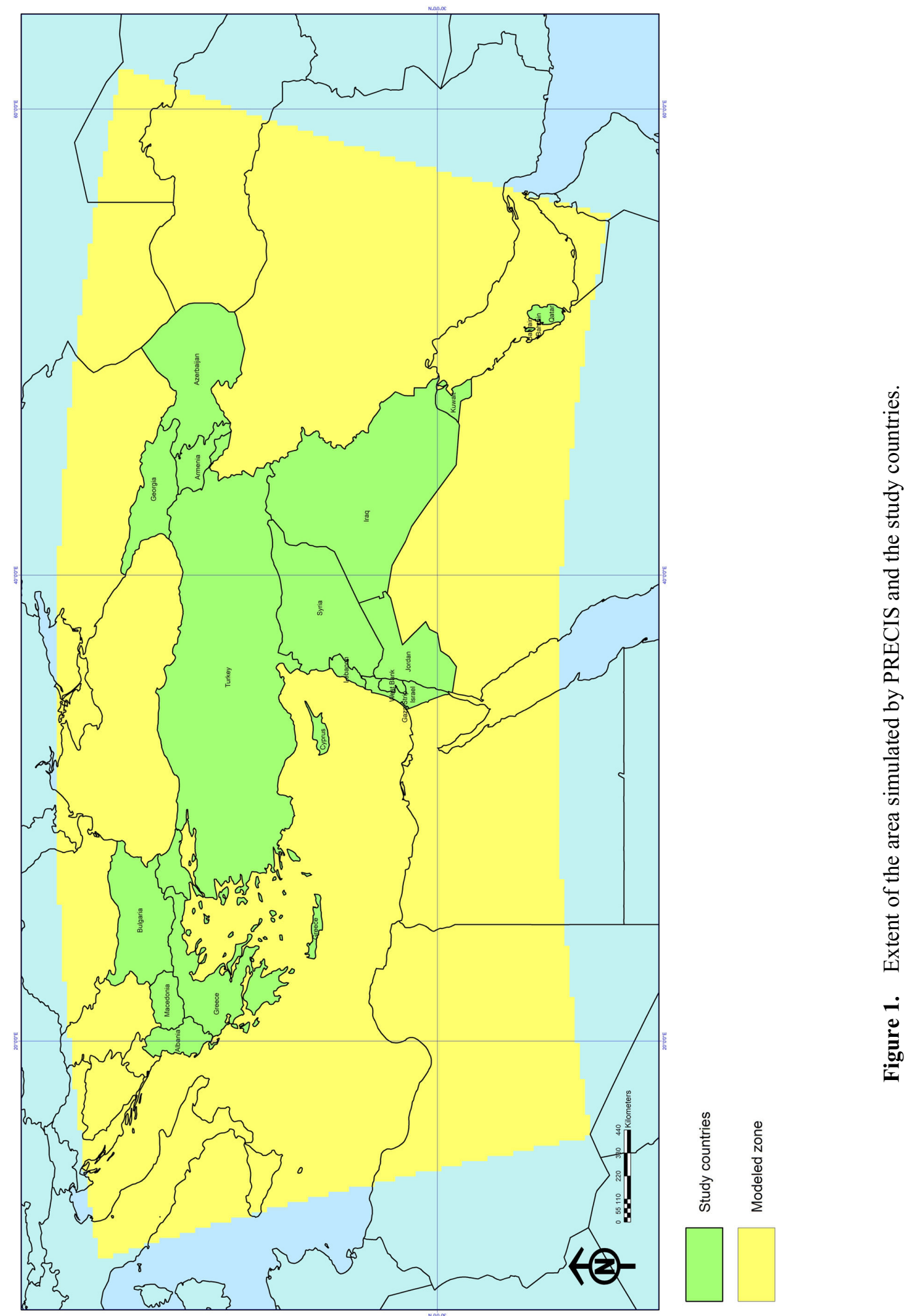


Table 1. Basic Socioeconomic and Water Resources Data for the Study Countries ${ }^{\mathrm{a}}$

\begin{tabular}{|c|c|c|c|c|c|c|c|c|}
\hline Country & $\begin{array}{l}\text { Area } \\
\left(\mathrm{km}^{2}\right)\end{array}$ & $\begin{array}{l}\text { Human } \\
\text { Development } \\
\text { Level }\end{array}$ & $\begin{array}{l}\text { GDP per } \\
\text { Capita } \\
\text { (PPP \$) }\end{array}$ & $\begin{array}{l}2009 \\
\text { Population } \\
\left(\times 10^{6}\right)\end{array}$ & $\begin{array}{c}\text { Mean Precipitation } \\
\text { Depth } \\
\left(\mathrm{mmol} \mathrm{yr}^{-1}\right)\end{array}$ & $\begin{array}{l}\text { Volume of } \\
\text { Precipitation } \\
\left(\mathrm{km}^{3} \mathrm{yr}^{-1}\right)\end{array}$ & $\begin{array}{c}\text { Internal Renewable } \\
\text { Water Resources } \\
\left(\mathrm{km}^{3} \mathrm{yr}^{-1}\right)\end{array}$ & $\begin{array}{l}\text { Current Water Withdrawals } \\
\text { as a Percentage of Total } \\
\text { Renewable Water Resources }\end{array}$ \\
\hline Albania & 28,750 & high & 7,976 & 3.155 & 1,485 & 42.7 & 26.9 & 4.1 \\
\hline Armenia & 29,800 & high & 5,495 & 3.083 & 562 & 16.8 & 9.1 & 26.8 \\
\hline Azerbaijan & 86,600 & high & 8,747 & 8.832 & 447 & 38.7 & 8.1 & 39.8 \\
\hline Bahrain & 710 & very high & 26,664 & 0.791 & 83 & 0.1 & 0.0 & 205.8 \\
\hline Bulgaria & 111,000 & high & 11,139 & 7.545 & 608 & 67.4 & 21.0 & 49.3 \\
\hline Cyprus & 9,250 & very high & 21,962 & 0.871 & 498 & 4.6 & 0.8 & 26.5 \\
\hline FYROM & 25,710 & high & 9,487 & 2.000 & 619 & 15.9 & 5.4 & 24.3 \\
\hline Georgia & 69,700 & high & 4,902 & 4.260 & 1,026 & 71.5 & 58.1 & 2.6 \\
\hline Greece & 131,960 & very high & 27,580 & 11.161 & 652 & 86.1 & 58.0 & 10.5 \\
\hline Iraq & 438,320 & - & - & 30.747 & 216 & 94.7 & 35.2 & 85.3 \\
\hline Israel & 22,070 & very high & 27,831 & 7.170 & 435 & 9.2 & 0.8 & 92.9 \\
\hline Jordan & 88,780 & high & 5,956 & 6.316 & 111 & 9.9 & 0.7 & 90.9 \\
\hline Kuwait & 17,820 & high & 55,719 & 2.985 & 121 & 2.2 & 0.0 & 2075 \\
\hline Lebanon & 10,400 & - & 13,475 & 4.224 & 661 & 6.9 & 4.8 & 28 \\
\hline $\begin{array}{l}\text { Palestinian } \\
\text { territories }\end{array}$ & 6,220 & - & - & 4.277 & 402 & 2.42 & 0.81 & 50 \\
\hline Qatar & 11,000 & very high & 79,426 & 1.409 & 74 & 0.8 & 0.1 & 417 \\
\hline Syria & 185,180 & medium & 4,760 & 21.906 & 252 & 46.7 & 7.0 & 61.5 \\
\hline Turkey & 783,560 & high & 13,359 & 74.817 & 593 & 459.5 & 227.0 & 18.3 \\
\hline
\end{tabular}

${ }^{a}$ Sources are the Food and Agriculture Organization (FAO, AQUASTAT, 2009), United Nations Population Division [2009], and United Nations Development Programme [2010]. GDP, gross domestic product; PPP, purchasing power parity; FYROM, former Yugoslav Republic of Macedonia. All dollar values are given in U.S. dollars.

destabilizing effect in the region by increasing tensions within and between countries as both river basins contribute a substantial proportion of available water resources to some of their riparian countries.

[10] The socioeconomic data used in this paper are primarily drawn from United Nations sources. Economic data are from the Human Development Reports of the United Nations Development Programme (UNDP), which provide data for a multitude of development-related indicators. Population data are from the United Nations Population Division, which develops annual estimates of global human population through 2050, producing low, medium, and high variants of its estimates. While projections of future population based on natural increase can be made with some degree of accuracy up to a generation ahead, projecting population growth rates more than a generation ahead is fraught with difficulties. Such projections require demographers to try to predict the family size choices of a yet unborn generation on the basis of recent trends, and thus, they rarely stand the test of time. For example, the U.S. government's Research Committee on Social Trends in 1933 predicted that the U.S. population would grow to be between 145 and 190 million by the end of the century (with the lower figure considered more likely) [Dorn, 1950], yet even this generously large projection range did not capture the actual population of the United States in 2000, which was 288 million [United Nations Population Division, 2009].

[11] Long-term population projections are derived using the cohort-component approach, which is based upon agespecific mortality and fertility rates for the population size and age distribution [Goldstein and Stecklov, 2002]. This approach works well for short-run projections, but for longterm projections, results are increasingly dependent upon the assumed rates of change in fertility and mortality rates rather than the actual starting population further into the future. Thus, it makes little sense examining population projections beyond 2050 since they are no better than guess work.

[12] The climate change on the EMME region was projected using the PRECIS regional climate model (RCM), which was developed by the Hadley Centre with a spatial resolution of $0.22^{\circ}$ by $0.22^{\circ}$, approximately $25 \mathrm{~km} \times 25 \mathrm{~km}$. PRECIS is a version of the Hadley Centre's RCM HadRM3P, which is based upon the atmospheric component of the coupled atmosphere-ocean global climate model HadCM3. PRECIS simulates dynamical flow and the atmospheric sulfur cycle and includes physical parameterizations for clouds and precipitation, radiative processes, the land surface, and deep soil [Jones et al., 2004].

[13] PRECIS was run from 1950 to 2099 (P. Hadjinicolaou, E. Tyrlis, G. Zittis, M. Tanarhte, and J. Lelieveld, Simulation of recent past and 21 st century climate in the eastern Mediterranean and the Middle East with the PRECIS regional climate model, abstract EGU2011-9429 presented at Eur. Geosci. Union General Assembly, Vienna, 2011), forced by lateral boundary conditions from the HadCM3, driven by the A1B emission scenario developed by the Intergovernmental Panel on Climate Change (IPCC) [2000]. The A1B scenario assumes very rapid economic growth, low population growth, with human population peaking midcentury, and the rapid introduction of new and more efficient technologies [IPCC, 2000]. The A1B scenario is a midrange scenario. The best estimate of global mean temperature increase in 2090-2099 relative to $1980-$ 1999 is $2.8^{\circ} \mathrm{C}$ for the $\mathrm{A} 1 \mathrm{~B}$ scenario, compared to $4.0^{\circ} \mathrm{C}$ for the A1FI scenario and $1.8^{\circ} \mathrm{C}$ for the $\mathrm{B} 1$ scenario [IPCC, 2007].

\section{Methodology}

[14] The model outputs from PRECIS were analyzed using ArcMap GIS software to calculate annual averages of a given parameter for the land area as a whole of each study 
country. For example, using PRECIS' precipitation output for the 1961-1990 period, ArcMap estimated an annual precipitation for the Gaza Strip of $122 \mathrm{~mm} \mathrm{yr}^{-1}$. Being a very small territory, only $360 \mathrm{~km}^{2}$ in area compared to the $625 \mathrm{~km}^{2}$ resolution of PRECIS model cells, and not fitting wholly within a single cell of the model outputs, the Gaza Strip spans three cells. Very roughly, $30 \%$ of the territory occurs within a cell of $126 \mathrm{~mm}$ precipitation, $30 \%$ occurs within a cell of $177 \mathrm{~mm}$ precipitation, and $40 \%$ occurs within a cell of $82 \mathrm{~mm}$. The weighted average for the territory is $122 \mathrm{~mm}$ of precipitation per year. The small size of the Gaza Strip and other study countries like Bahrain is problematic when calculating annual precipitation or internal water resources as the position of territory relative to individual model cells can significantly influence the result. Nevertheless, for climate change the relative difference in rainfall is relevant, so the results are considered meaningful from this perspective.

[15] The PRECIS simulations were used to calculate precipitation changes for the 2040-2069 and 2070-2099 time periods with respect to 1961-1990. The percentage change in internal water resources was estimated on the basis of the assumption that the percentage of precipitation lost to evapotranspiration remains constant. Thus, the projected change in internal water resources is assumed to be the same as the projected change in precipitation. Consideration was given to using the PRECIS model outputs for evapotranspiration to calculate change in evapotranspiration rates relative to the reference period and thus to permit more precise estimations of future water resources availability. However, the lack of water balance accounting in PRECIS meant that evapotranspiration model outputs were not sufficiently credible. While higher temperatures will mean greater potential evapotranspiration, actual evapotranspiration is determined by vegetation and soil moisture levels and the nature of the precipitation regime. Elasticities of streamflow are typically high in semiarid catchments, with a $1 \%$ change in annual precipitation typically leading to a $2.0 \%-3.5 \%$ change in annual streamflow [Chiew, 2006]. In the countries of the EMME region, during the wet winter months, when precipitation is higher than potential evapotranspiration, higher temperatures could result in a decrease of the part of the rain that turns into water resources. However, during the majority of the year, potential evapotranspiration is higher than the precipitation, and an increase in temperature will have little effect on the generation of water resources. Thus, the assumption that the change in internal water resources will be the same as the projected change in precipitation may produce an optimistic estimate of internal water resources. Oroud [2010], for example, estimated in the case of the upper Jordan basin that a $2^{\circ}$ increase in temperature coupled with a $10 \%$ decrease in precipitation results in a $45 \%-60 \%$ reduction in water yield from the basin.

[16] The AQUASTAT estimate of the volume of precipitation of a country is increased or decreased by the percentage change in precipitation estimated by PRECIS. Mean annual internal water resources for each study country were also increased or decreased by the percentage change in precipitation estimated by PRECIS. A similar method is used to calculate changes in water availability in international river basins, whereby the discharge volumes of the different subbasins of the river basin were increased or decreased by the percentage change in precipitation.
[17] Expressing this change in the form of equations, we have

$$
\begin{aligned}
\mathrm{PVol}_{t_{1}} & =\frac{\mathrm{AqPVol} t_{t_{0}} \mathrm{PcP}_{t_{1}}}{\mathrm{PcP}_{t_{0}}}, \\
\operatorname{Iwr}_{t_{1}} & =\frac{\mathrm{AqIwr}_{t_{0}} \mathrm{PcP}_{t_{1}}}{\mathrm{PcP}_{t_{0}}},
\end{aligned}
$$

where

PVol precipitation volume;

AqPVol AQUASTAT precipitation volume;

PcP PRECIS precipitation depth;

AqIwr AQUASTAT internal water resources volume;

Iwr internal water resources;

$t_{0} \quad$ reference period;

$t_{1} \quad$ future time period 1 (e.g., 2040-2059).

\section{Results : Physical Changes in Water Resources} 4.1. Assessment of the Model Performance

[18] PRECIS was used to model the climate conditions of the reference period 1961-1990 in the study region to provide a baseline for assessing its accuracy and for assessing the relative change for the future assessment periods. The annual precipitation estimate over the study countries from PRECIS for the period 1961-1990 (522 $\mathrm{mm} \mathrm{yr}^{-1}$ ) was around $6 \%$ higher than the AQUASTAT value $(491 \mathrm{~mm})$. When the differences in PRECIS precipitation are compared against those of the AQUASTAT data set on a country by country basis, PRECIS performs less well, with an average difference of around $27 \%$. This may partly be related to the coarse representation of surface topography in the model (at $25 \mathrm{~km}$ resolution). For the 1961-1990 period, PRECIS seems to consistently underestimate precipitation in the Levant region, while it overestimates precipitation in Turkey and the western Caucasus mountains. However, it should be considered that the AQUASTAT precipitation data have been interpolated from a limited number of rain gauges, so these data may also not represent the actual precipitation pattern accurately. Table 2 shows a comparison of annual precipitation values derived from AQUASTAT, CRU, and PRECIS for the 1961-1990 period.

[19] Examining relative change of the PRECIS simulations reduces but does not eliminate the problem of modeling uncertainties. For the 2040-2069 period, for only six countries (Albania, Azerbaijan, Greece, Lebanon, Qatar, and Syria) did the relative change (\%) in annual precipitation modeled for the 2040-2069 period relative to 1961-1990 exceed the difference between the 1961-1990 simulation and the AQUASTAT precipitation data. For the 2080-2099 period the modeled change in annual precipitation exceeded this difference for seven countries (Albania, Azerbaijan, Bahrain, Greece, Jordan, Lebanon, Qatar, and Syria). Given the modeling uncertainties, all results need to be treated cautiously.

[20] The PRECIS precipitation simulations were compared on a point-by-point basis with the model outputs of an ensemble of 16 general circulation models (GCMs), which were bias corrected and statistically downscaled to a $0.5^{\circ}$ grid, as described by Wood et al. [2004]. Comparisons 
Table 2. Comparison of Mean Precipitation of the Study Countries Between AQUASTAT Data and Data Derived From CRU and PRECIS Projections for 1961-1990 Using ArcMap GIS Software

\begin{tabular}{|c|c|c|c|c|c|c|}
\hline Country & 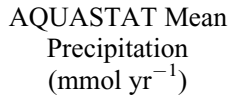 & $\begin{array}{l}\text { CRU Mean } \\
\text { Precipitation } \\
\left(\text { mmol yr }^{-1}\right)\end{array}$ & $\begin{array}{c}\text { Percentage Difference } \\
\text { of CRU } \\
\text { From AQUASTAT }\end{array}$ & $\begin{array}{l}\text { PRECIS Mean } \\
\text { Precipitation } \\
\left(\mathrm{mmol} \mathrm{yr}^{-1}\right)\end{array}$ & $\begin{array}{c}\text { Percentage Difference } \\
\text { of PRECIS } \\
\text { From AQUASTAT }\end{array}$ & $\begin{array}{c}\text { Percentage Difference } \\
\text { of PRECIS } \\
\text { From CRU }\end{array}$ \\
\hline Albania & 1485 & 1152 & -22.4 & 1452 & -2.2 & 26.1 \\
\hline Armenia & 562 & 549 & -2.4 & 932 & 65.9 & 69.9 \\
\hline Azerbaijan & 447 & 453 & 1.2 & 450 & 0.8 & -0.5 \\
\hline Bahrain & 83 & 80 & -4.1 & 98 & 17.9 & 22.9 \\
\hline Bulgaria & 608 & 639 & 5.0 & 755 & 24.1 & 18.2 \\
\hline Cyprus & 498 & 490 & -1.6 & 330 & -33.8 & -32.7 \\
\hline FYROM & 619 & 669 & 8.2 & 814 & 31.5 & 21.6 \\
\hline Georgia & 1026 & 1070 & 4.3 & 1410 & 37.4 & 31.8 \\
\hline Greece & 652 & 700 & 7.3 & 730 & 12.0 & 4.4 \\
\hline Iraq & 216 & 211 & -2.5 & 163 & -24.7 & -22.7 \\
\hline Israel & 435 & 288 & -33.8 & 174 & -60.0 & -39.6 \\
\hline Jordan & 111 & 119 & 7.4 & 88 & -20.8 & -26.3 \\
\hline Kuwait & 121 & 116 & -3.8 & 63 & -48.1 & -46.1 \\
\hline Lebanon & 661 & 711 & 7.5 & 649 & -1.8 & -8.6 \\
\hline $\begin{array}{c}\text { Palestinian } \\
\text { territories }\end{array}$ & 402 & 489 & 21.6 & 201 & -49.9 & -58.8 \\
\hline Qatar & 74 & 73 & -0.8 & 76 & 2.9 & 3.7 \\
\hline Syria & 252 & 314 & 24.6 & 219 & -13.0 & -30.2 \\
\hline Turkey & 593 & 602 & 1.5 & 791 & 33.4 & 31.5 \\
\hline
\end{tabular}

were made for the middle (2050s) and end (2080s) of the century for the A1B emission scenario across the study area (Table 3). These GCMs lack the resolution of RCMs and also do not pick up local environmental conditions as effectively as PRECIS. In seven of the nine locations compared, the PRECIS precipitation value falls within the range of the precipitation outputs of the GCMs for both future periods, with those locations outside the range being areas of extreme aridity and high variability in GCM model predictions. The wide range of the results of the GCM ensemble indicates the uncertainty in climate change model projections. While it may be possible to characterize model uncertainty, there is no immediate prospect of reducing the uncertainty [Wilby, 2010]. However, as noted by Foley [2010], we cannot wait for uncertainty in climate model outputs to be eliminated before making decisions about adaptation.

\subsection{Changes to Precipitation and Internal Water Resources by 2040-2069}

[21] According to the PRECIS simulations, the mean annual precipitation in the study countries changes from 491 $\mathrm{mm}$ in the 1961-1990 period to $443 \mathrm{~mm}$ in the $2040-2069$, thus giving an overall decline of $10 \%$. However, five countries (Armenia, Bahrain, Georgia, Kuwait, and Qatar) show increases in annual precipitation. Among those countries, in all cases except Qatar, the PRECIS percentage difference to the reference period was greater than the percentage change in 2040-2069, suggesting that these results need to be treated cautiously. While Bahrain, Kuwait, and Qatar are projected to have precipitation (and thus water resources) increases, the absolute size of the increase is insignificant because of their current lack of water resources. Nine countries have a mean precipitation decrease of more than $10 \%$, and of these nine countries, for four (Albania, Greece, Lebanon, and Syria) the modeled relative change was greater than the difference between the 1961-1990 model results and AQUASTAT. Cyprus and Lebanon are both projected to have a decrease in precipitation of greater than
$20 \%$. On the basis of the assumption that internal water resources change in line with precipitation across the region as a whole, internal water resources decrease from 464 to $419 \mathrm{~km}^{3}$. Figure 2 shows the percentage increase in precipitation in 2040-2069 relative to 1961-1990. Table 4 shows the modeled effects of climate change on water resources for the study countries for 2040-2069 and 2070-2099.

\subsection{Changes to Precipitation and Internal Water Resources by 2070-2099}

[22] The modeling results from PRECIS for the A1B scenario for the end of the century period of 2070-2099 suggest a small further decline in annual precipitation across the region from midcentury. The mean annual precipitation depth in the study countries decreases from 443 $\mathrm{mm}$ in the period 2040-2069 to $436 \mathrm{~mm}$ in $2070-2099$, thus giving an average further decline in each country of $1.5 \%$ relative to midcentury and $11 \%$ relative to $1961-$ 1990. Four countries (Bahrain, Georgia, Kuwait, and Qatar) are projected to have a precipitation increase, but as with midcentury precipitation estimates, the absolute size of the increase is insignificant in all of these cases except Georgia, where the increase is still a modest $1.3 . \mathrm{km}^{3}$. Eleven countries experience a decrease in precipitation of more than $10 \%$ relative to $1961-1990$, and four countries (Greece, Jordan, Lebanon, and the Palestinian territories) experience precipitation decreases of more than $20 \%$. In the cases of Greece, Jordan, and Lebanon, this decrease is greater than the difference between the 1961-1990 model results and AQUASTAT. In the case of Cyprus, while precipitation still decreases by $17 \%$ relative to $1961-1990$, precipitation increases by $4 \%$ relative to midcentury.

[23] Across the region as a whole, internal water resources decrease from $464 \mathrm{~km}^{3}$ in $1961-1990$ to $412 \mathrm{~km}^{3}$ in 2070-2099. Figure 3 shows percentage increase in precipitation for 2070-2099 over the study area relative to 1961-1990. 


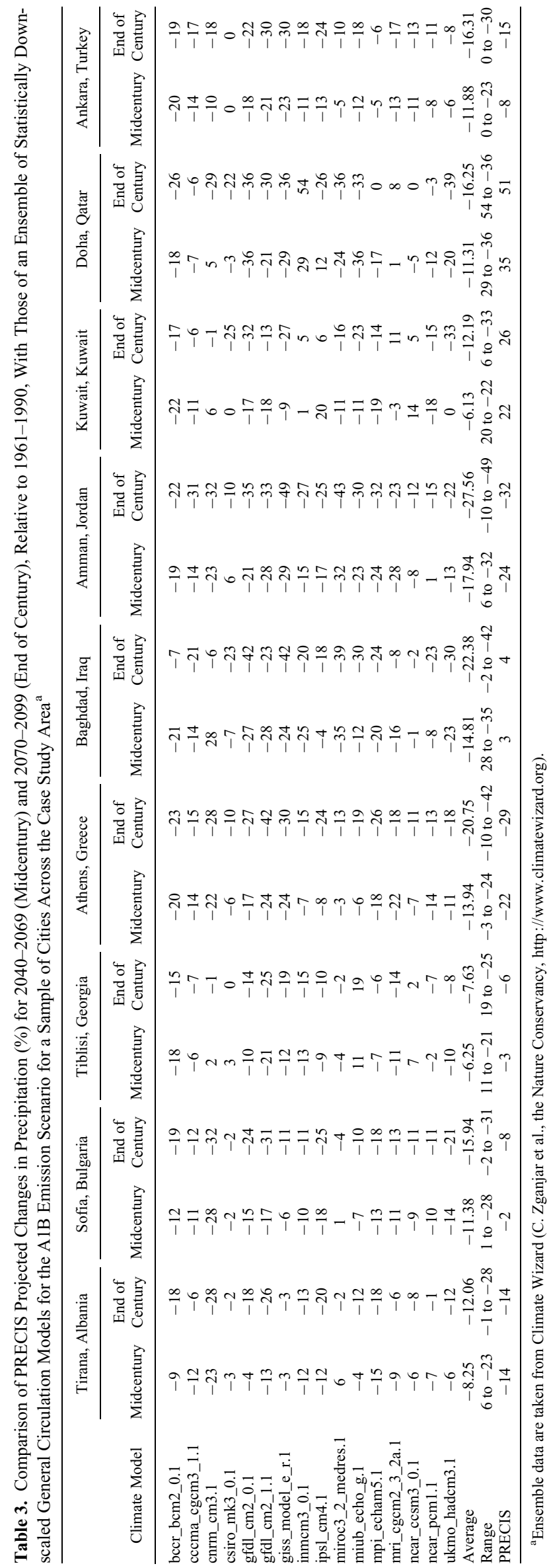



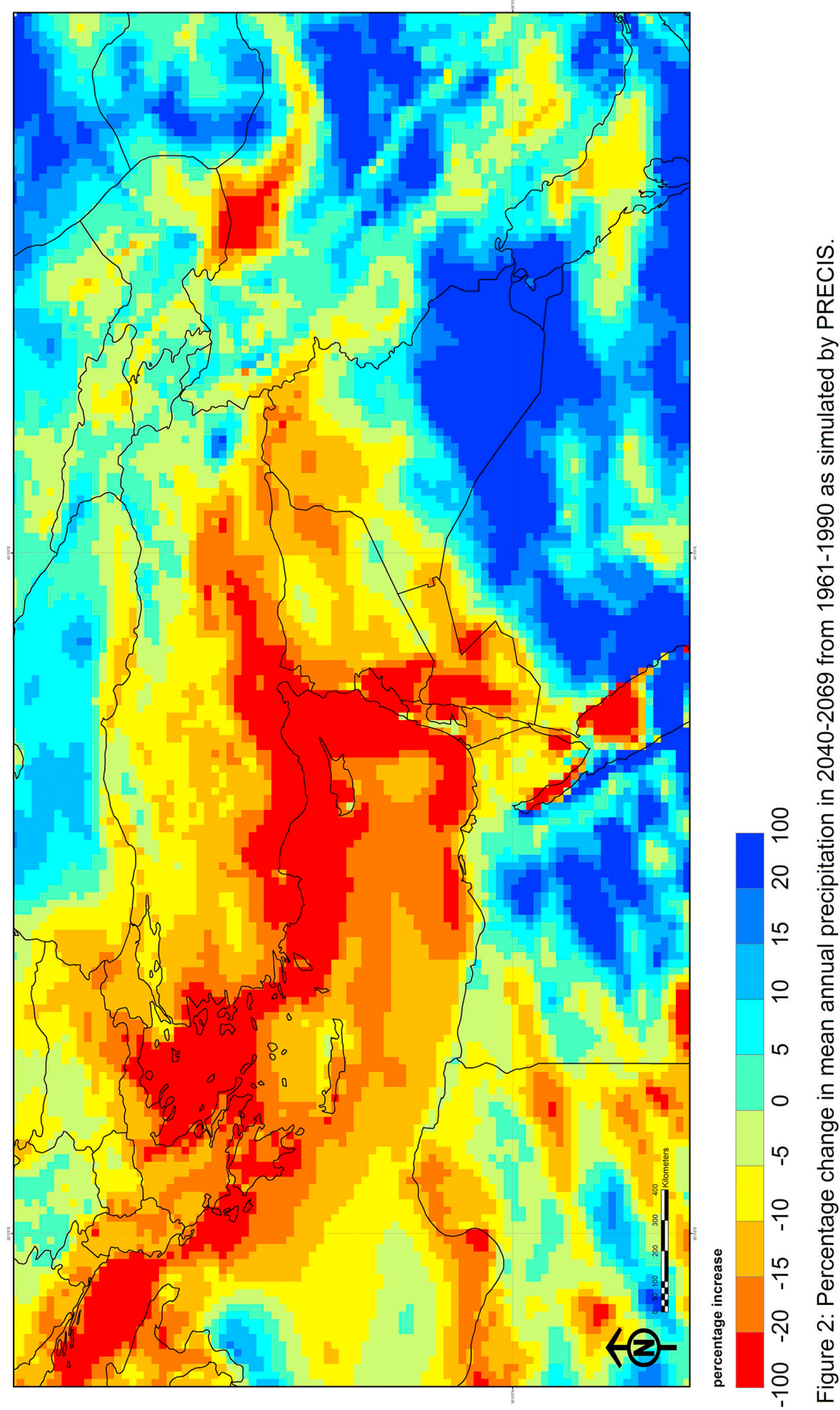

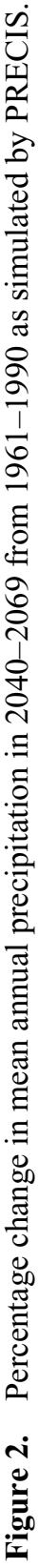


Table 4. Modeled Effects of Climate Change on Water Resources of the Study Countries for 2040-2069 and 2070-2099 for IPCC SRES Scenario A1B, as Calculated From the PRECIS Projections Using ArcMap GIS Software and the Equations in Section 3

\begin{tabular}{|c|c|c|c|c|c|c|c|}
\hline \multirow[b]{2}{*}{ Country } & \multicolumn{3}{|c|}{ 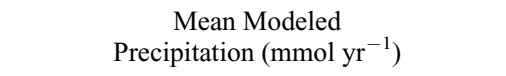 } & \multirow{2}{*}{$\begin{array}{l}\text { Mean Change in } \\
\text { Precipitation in } \\
\text { 2040-2069 From } \\
1961-1990(\%)\end{array}$} & \multirow{2}{*}{$\begin{array}{c}\text { Internal Renewable } \\
\text { Water Resources in } \\
2040-2069 \\
\left(\mathrm{~km}^{3} \mathrm{yr}^{-1}\right)\end{array}$} & \multirow{2}{*}{$\begin{array}{l}\text { Mean Change in } \\
\text { Precipitation in } \\
\text { 2070-2099 From } \\
\text { 1961-1990 (\%) }\end{array}$} & \multirow{2}{*}{$\begin{array}{c}\text { Internal Renewable } \\
\text { Water Resources in } \\
2070-2099 \\
\left(\mathrm{~km}^{3} \mathrm{yr}^{-1}\right)\end{array}$} \\
\hline & 1961-1990 & 2040-2069 & $2070-2099$ & & & & \\
\hline Albania & 1452 & 1252 & 1249 & -13.8 & 23.2 & -14.0 & 23.1 \\
\hline Armenia & 932 & 936 & 924 & 0.4 & 9.1 & -0.9 & 9.0 \\
\hline Azerbaijan & 450 & 446 & 445 & -1.1 & 8.0 & -1.2 & 8.0 \\
\hline Bahrain & 98 & 103 & 142 & 5.2 & 0.0 & 45.0 & 0.0 \\
\hline Bulgaria & 755 & 688 & 661 & -8.8 & 19.1 & -12.5 & 18.4 \\
\hline Cyprus & 330 & 263 & 274 & -20.3 & 0.6 & -17.0 & 0.6 \\
\hline FYROM & 814 & 734 & 701 & -9.8 & 4.9 & -13.9 & 4.6 \\
\hline Georgia & 1410 & 1421 & 1442 & 0.8 & 58.6 & 2.2 & 59.4 \\
\hline Greece & 730 & 601 & 567 & -17.7 & 47.7 & -22.4 & 45.0 \\
\hline Iraq & 163 & 158 & 155 & -3.0 & 34.1 & -4.9 & 33.5 \\
\hline Israel & 174 & 151 & 141 & -12.9 & 0.7 & -18.8 & 0.6 \\
\hline Jordan & 88 & 73 & 69 & -16.6 & 0.6 & -21.1 & 0.5 \\
\hline Kuwait & 63 & 82 & 83 & 30.7 & 0.0 & 31.4 & 0.0 \\
\hline Lebanon & 649 & 494 & 449 & -23.9 & 3.7 & -30.9 & 3.3 \\
\hline $\begin{array}{c}\text { Palestinian } \\
\text { territories }\end{array}$ & 201 & 172 & 154 & -14.7 & 0.7 & -23.3 & 0.6 \\
\hline Qatar & 76 & 97 & 118 & 27.9 & 0.1 & 55.2 & 0.1 \\
\hline Syria & 219 & 189 & 184 & -13.7 & 6.0 & -16.1 & 5.9 \\
\hline Turkey & 791 & 704 & 694 & -11.0 & 202.0 & -12.2 & 199.2 \\
\hline
\end{tabular}

\subsection{Projected Effects of Climate Change on International River Flows}

[24] The Euphrates River is $3000 \mathrm{~km}$ long, with a basin area of $879,790 \mathrm{~km}^{2}$. According to the FAO (FAO, AQUASTAT, 2009), Turkey contributes $89 \%\left(28.1 \mathrm{~km}^{3}\right.$ of water $)$ of its annual discharge, while Syria contributes $11 \%$, and the remaining riparian countries contribute negligible amounts. The Tigris River is $1850 \mathrm{~km}$ long, with Turkey providing $51 \%\left(21.3 \mathrm{~km}^{3}\right)$ of its annual natural discharge, Iraq $39 \%$, and Iran $10 \%$ [FAO, 2009]. The Shatt Al-Arab is the river formed by the confluence of the Tigris and Euphrates, which flows into the Persian Gulf. Just prior to entering the Persian Gulf, the Shatt Al-Arab is joined by the Karun River, which adds a significant amount of additional fresh water. The average annual discharge rate of the Tigris-Euphrates is difficult to determine because of significant interannual variation in river flows, with annual discharges varying from as low as $30 \mathrm{~km}^{3}$ to as much as 84 $\mathrm{km}^{3}$ [FAO, 2009]. Table 5 shows the volumetric contributions of each of the riparian nations to the Tigris-Euphrates river basin on the basis of the estimates of the FAO, which suggest that the annual discharge averages $73.4 \mathrm{~km}^{3}$. This estimate is comparable to the $80 \mathrm{~km}^{3}$ computed value modeled by Jones et al. [2008] using streamflow gauge data for the period of 1965-1973.

[25] The PRECIS model outputs suggest that the average annual Tigris-Euphrates river discharge could decline by $9.5 \%$ by the $2040-2069$ period. The decline is greatest in Turkey at $12 \%$, while it is only $4 \%$ in Iraq. There is a further decrease in river discharge by 2070-2099; however, the decrease is less than $1 \%$. This end of the century estimate of a $10 \%$ decrease in overall river basin discharge is lower than that by Kitoh et al. [2008], who estimated a discharge decrease of between $29 \%$ and $73 \%$ for the Euphrates River for 2080-2099, depending upon the climate change scenario considered. However, the projections of Kitoh et al. [2008] were questioned by Ben-Zvi and
Givati [2008], who suggested that the large differences between the simulated and observed values for the Jordan River system in the model used by Kitoh et al. meant that their results were of questionable validity. See Table 5 for the modeled discharge data.

[26] The Jordan River is $250 \mathrm{~km}$ long, with a catchment area of $18,500 \mathrm{~km}^{2}[F A O, 2009]$. The three headwater springs of the Jordan, the Dan, the Hasbani, and the Banias, together contribute approximately $0.504 \mathrm{~km}^{3} \mathrm{yr}^{-1}$ to the Jordan's discharge, with local runoff in the Hulah Valley contributing another $0.140 \mathrm{~km}^{3}$, but there is a net loss of $0.070 \mathrm{~km}^{3}$ because of evaporation over Lake Tiberius [Murakami, 1995]. Thus, the upper Jordan basin contributes approximately $0.574 \mathrm{~km}^{3}$ of water to the basin. Downstream of Lake Tiberius, the Yarkmouk River contributes $0.400 \mathrm{~km}^{3}$, with the remainder of the east bank of the Jordan River contributing $0.207 \mathrm{~km}^{3}$ from various wadis and springs [Murakami, 1995]. Another $20 \%\left(0.105 \mathrm{~km}^{3}\right)$ of the lower Jordan's discharge comes from Israel, with the remainder of the river's discharge $\left(0.211 \mathrm{~km}^{3}\right)$ coming from the West Bank. As with the Tigris-Euphrates river basin, the Jordan's annual discharge rate is extremely variable, with inflows into the Dead Sea, the highly saline terminal lake of the Jordan River basin, being massively reduced in recent decades compared to natural conditions because of irrigation and water diversions upstream.

[27] The PRECIS simulations indicate that available water resources in the Jordan River basin will decline during the course of this century, suggesting a $22 \%$ fall by 2040-2069 and a 30\% fall by 2070-2099, with the decrease being relatively even across the catchment. This decline in the Jordan River discharge is significantly less than that estimated by Kitoh et al. [2008], who estimated an $82 \%$ $98 \%$ decrease in the discharge of the river for the 2080 2099 period, depending upon the climate change scenario considered. However, this PRECIS modeled decline in discharge is comparable to but slightly greater than that 

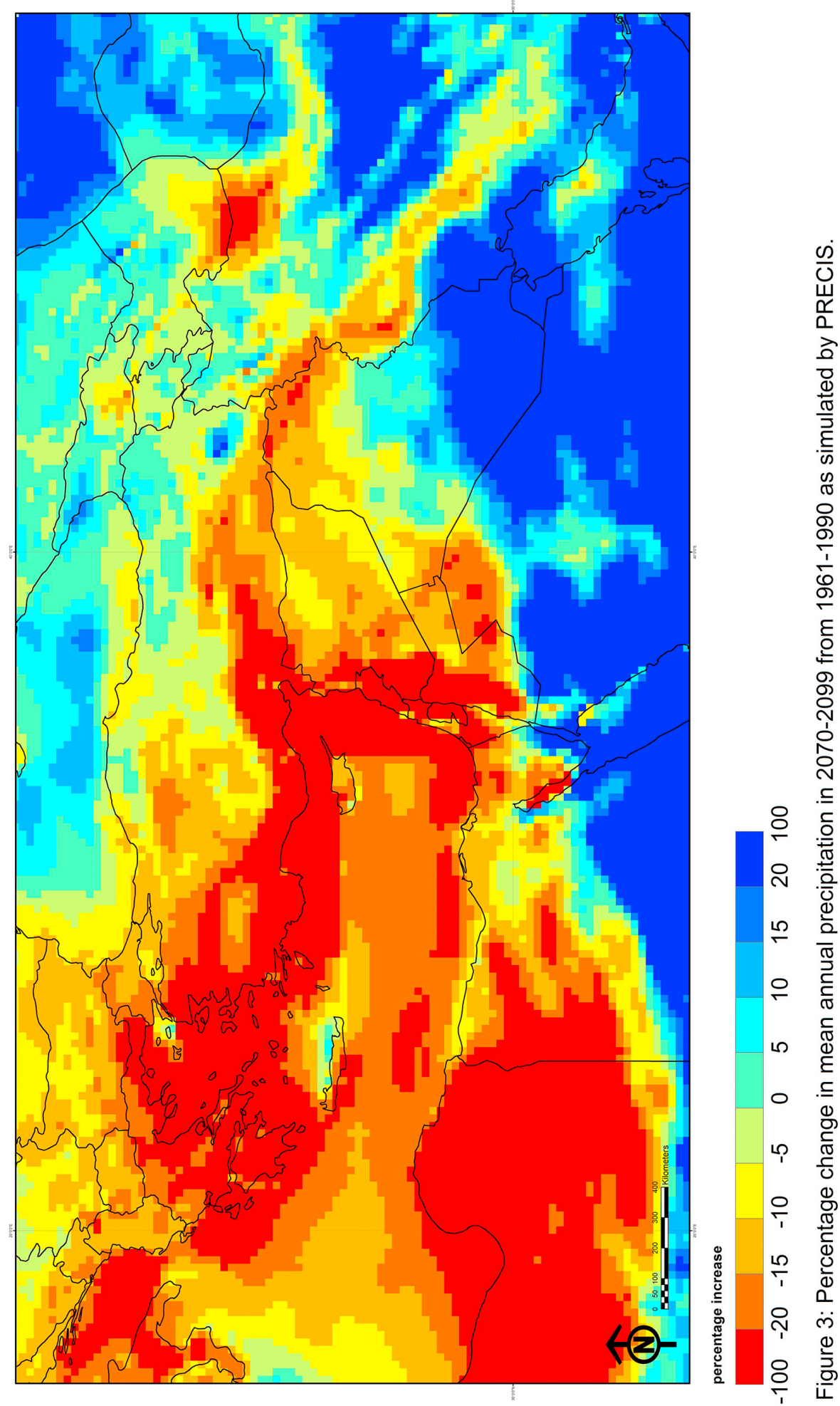

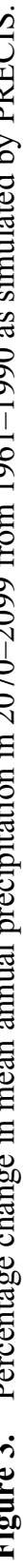




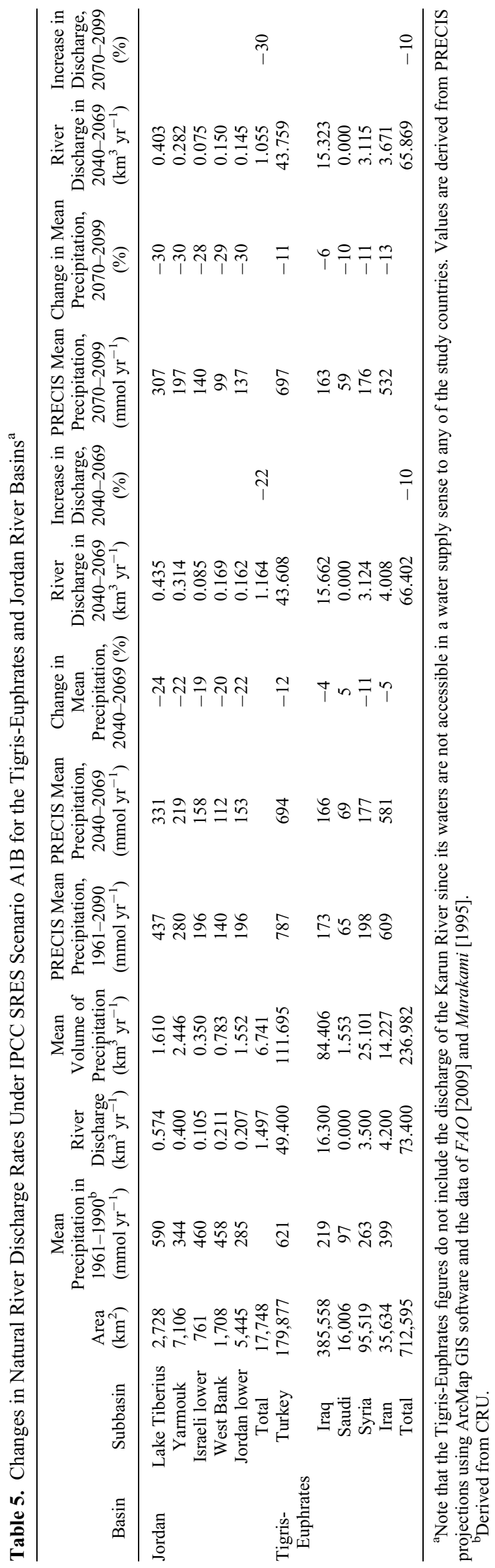

modeled by Kunstmann et al. [2009], who estimated a $10 \%-15 \%$ decrease in precipitation in the upper part of the Jordan basin in the 2035-2060 period, compared to the PRECIS-modeled decrease in precipitation in 2040 2059 of $17 \%$ for the same region. The PRECIS estimate is also comparable to that of Samuels et al. [2010], who estimated, using a downscaled RCM, that there would be a $10 \%$ reduction in annual precipitation, a $10 \%-11 \%$ reduction in daily mean base flow, and a $17 \%$ reduction in daily mean surface flow in the 2036-2060 period relative to the 1980-2004 period in the upper catchment of the Jordan River.

\subsection{Effects of Population Change and Economic Development on Water Resources}

[28] There is a diversity of levels of economic and social development across the study area, which means that a diversity of adaptation approaches to future climate change will be required. While five countries (Bahrain, Cyprus, Greece, Israel, and Qatar) are considered by the UNDP to have very high levels of human development, the majority of countries are considered to have medium or high human development [United Nations Development Programme, 2010]. Iraq and the Palestinian territories are not classified in terms of human development by the UNDP. Per capita incomes (measured in purchasing power parity (PPP) \$ (all dollar values are given in U.S. dollars), which is a measure that converts different currency units on the basis of their purchasing power) in the study area in 2008 ranged from $\$ 79,426$ in Qatar to $\$ 4760$ in Syria [United Nations Development Programme, 2010]. (In comparison, per capita gross domestic product is $\$ 47,094$ in the United States and \$35,087 in the United Kingdom.)

[29] Population growth rates across the study region vary significantly and, indeed, range from among the fastest to slowest in the world. Over the 2005-2010 period, Qatar recorded the fastest population growth rate of any country in the world, with a population growth of $10.65 \%$ $\mathrm{yr}^{-1}$, while Georgia had the second fastest rate of decline after Niue [United Nations Population Division, 2009]. According to the United Nations Population Division's medium-variant estimate, by 2050, population growth will have significantly slowed across the region, with 9 out the of the 20 study countries recording negative population growth rates by then, and all but two countries having growth rates of less than $1 \%$. See Table 6 for a summary of United Nations population projections for the study countries.

[30] Internal renewable water resources currently range from $13,638 \mathrm{~m}^{3}$ per capita per year in Georgia to approximately zero in Bahrain and Kuwait, where water needs are currently met largely through desalination. Eight countries currently have less than $1000 \mathrm{~m}^{3}$ per capita per year, the threshold that is generally used to define water scarcity according to the commonly used Falkenmark definition [Falkenmark, 1992]. This definition is based upon the amount of water a country requires in order to achieve food self-sufficiency using irrigated agriculture in a semiarid environment. Two countries (Bahrain and Kuwait) currently have less than the $50 \mathrm{~m}^{3}$ per capita per year, the amount of water suggested by Chenoweth [2008] as the minimum amount of water required by a country for 
Table 6. Population Projections for the Study Countries ${ }^{\mathrm{a}}$

\begin{tabular}{|c|c|c|c|c|c|c|}
\hline \multirow[b]{2}{*}{ Country } & \multirow[b]{2}{*}{2009 Population $\left(\times 10^{6}\right)$} & \multicolumn{2}{|c|}{ Population Growth Rate (\%) } & \multicolumn{3}{|c|}{2050 Population $\left(\times 10^{6}\right)$} \\
\hline & & $2005-2010$ & 2040-2050 (Medium Variant) & Low Variant & Medium Variant & High Variant \\
\hline Albania & 3.155 & 0.37 & -0.29 & 2.823 & 3.303 & 3.842 \\
\hline Armenia & 3.083 & 0.17 & -0.39 & 2.589 & 3.018 & 3.495 \\
\hline Azerbaijan & 8.832 & 1.11 & -0.07 & 9.114 & 10.579 & 12.207 \\
\hline Bahrain & 0.791 & 2.08 & 0.56 & 1.125 & 1.277 & 1.44 \\
\hline Bulgaria & 7.545 & -0.64 & -0.95 & 4.711 & 5.392 & 6.16 \\
\hline Cyprus & 0.871 & 1.02 & 0.50 & 1.043 & 1.175 & 1.319 \\
\hline FYROM & 2.042 & 0.08 & -0.49 & 1.617 & 1.857 & 2.128 \\
\hline Georgia & 4.26 & -1.13 & -0.84 & 2.8 & 3.267 & 3.791 \\
\hline Greece & 11.161 & 0.22 & -0.20 & 9.714 & 10.939 & 12.266 \\
\hline Iraq & 30.747 & 2.17 & 1.09 & 55.802 & 63.995 & 72.828 \\
\hline Israel & 7.17 & 1.70 & 0.54 & 9.372 & 10.649 & 12.022 \\
\hline Jordan & 6.316 & 3.02 & 0.65 & 8.862 & 10.241 & 11.742 \\
\hline Kuwait & 2.985 & 2.44 & 0.78 & 4.646 & 5.24 & 5.884 \\
\hline Lebanon & 4.224 & 0.83 & 0.03 & 4.336 & 5.033 & 5.8 \\
\hline Palestinian territories & 4.277 & 3.18 & 1.41 & 8.992 & 10.265 & 11.627 \\
\hline Qatar & 1.409 & 10.65 & 0.71 & 2.128 & 2.316 & 2.52 \\
\hline Syria & 21.906 & 3.26 & 0.71 & 31.992 & 36.911 & 42.234 \\
\hline Turkey & 74.816 & 1.24 & 0.20 & 84.251 & 97.389 & 111.759 \\
\hline
\end{tabular}

${ }^{\mathrm{a}}$ The source is the work of the United Nations Population Division (http://esa.un.org/unpp/).

meeting domestic water needs and developing a water-efficient nonagricultural economy that permits social and economic development. Thus, both of these countries already depend upon desalination to meet most of their water needs. There is currently a divide between those countries that can easily afford to supplement their available freshwater resources through desalination as a result of their strong economic position, such as Bahrain, Israel, and $\mathrm{Ku}-$ wait, and those countries or regions that face significant financial difficulties doing so, such as Jordan and the Palestinian territories [Sowers et al., 2011]. Table 7 shows the projected per capita water resources for the study countries under a range of population scenarios.

[31] A country's water footprint is defined as the total volume of freshwater (both green and blue water) required to produce the goods and services consumed by the people of that country [Chapagain and Hoekstra, 2004b]. According to Chapagain and Hoekstra [2004b], the global average water footprint is $1243 \mathrm{~m}^{3}$ per capita per year. Among the study countries (for which there are data, thus excluding FYROM and the Palestinian territories), water footprints vary from $792 \mathrm{~m}^{3}$ per capita per year in Georgia (ironically, currently the most water plentiful of the study countries in per capita terms) to $2389 \mathrm{~m}^{3}$ per capita per year in Greece, with the average being $1391 \mathrm{~m}^{3}$ per capita per year [Chapagain and Hoekstra, 2004a]. There is only a weak correlation between water footprints and economic development; Syria, for example, has a water footprint of $1827 \mathrm{~m}^{3}$ per capita per year but is a medium-income country, while Qatar has a water footprint of $1087 \mathrm{~m}^{3}$ per capita per year but has the world's highest income level. These water footprints include all of the water used by a country, either directly within its borders or indirectly to produce the goods and services that it imports from other countries. The total water footprint of the study countries (for which there are data, thus excluding FYROM and the Palestinian territories) is $250 \mathrm{~km}^{3}$, of which $195 \mathrm{~km}^{3}$, or $78 \%$, are obtained internally and $55 \mathrm{~km}^{3}$ are imported. Thus, approximately $22 \%$ of the region's water needs are met through "virtual water": the import of water effectively embedded in products sourced externally.

[32] It is difficult to quantify the effect that climate change will have on virtual water requirements in the study countries as the water footprint data presented by Chapagain and Hoekstra [2004a] do not differentiate between water use via rain-fed agriculture (green water) and the use of water that is extracted from the environment as water (blue water). However, if the internal water footprint of the study countries declines in line with the precipitation decline modeled by 2040-2059, then the internal water footprint will reduce to $176 \mathrm{~km}^{3} \mathrm{yr}^{-1}$. Simultaneously, however, if the per capita water footprint does not change and thus the total (internal plus external) water footprint increases in line with population growth, then for the medium-variant population projection of the United Nations Population Division the total water footprint for the study countries increases to $361 \mathrm{~km}^{3}$ by midcentury. This would mean that the virtual water requirement of the region increases from approximately 55 to $185 \mathrm{~km}^{3} \mathrm{yr}^{-1}$, or from $22 \%$ of the total water footprint of the countries to $51 \%$. Thus, more than half the region's water needs may need to be met from external sources by midcentury unless water use efficiency improves. In reality, it is likely that the increase in virtual water would be somewhat smaller than this analysis suggests, as growing populations and declining water resources would likely lead to improvements in water use efficiency and an intensification of water resources use in the countries where water resources are not yet fully exploited. Whether such an increase in virtual water imports is possible will also depend upon the state of global markets, particularly for agricultural goods. These will be influenced by global population growth and economic development and the effects of climate change on global agriculture, particularly in the key agricultural export regions.

[33] Placing an economic value on the water resources lost as a result of climate change is problematic as value judgments are required. Where declining water resources result in no reduction of extracted water but reduced 


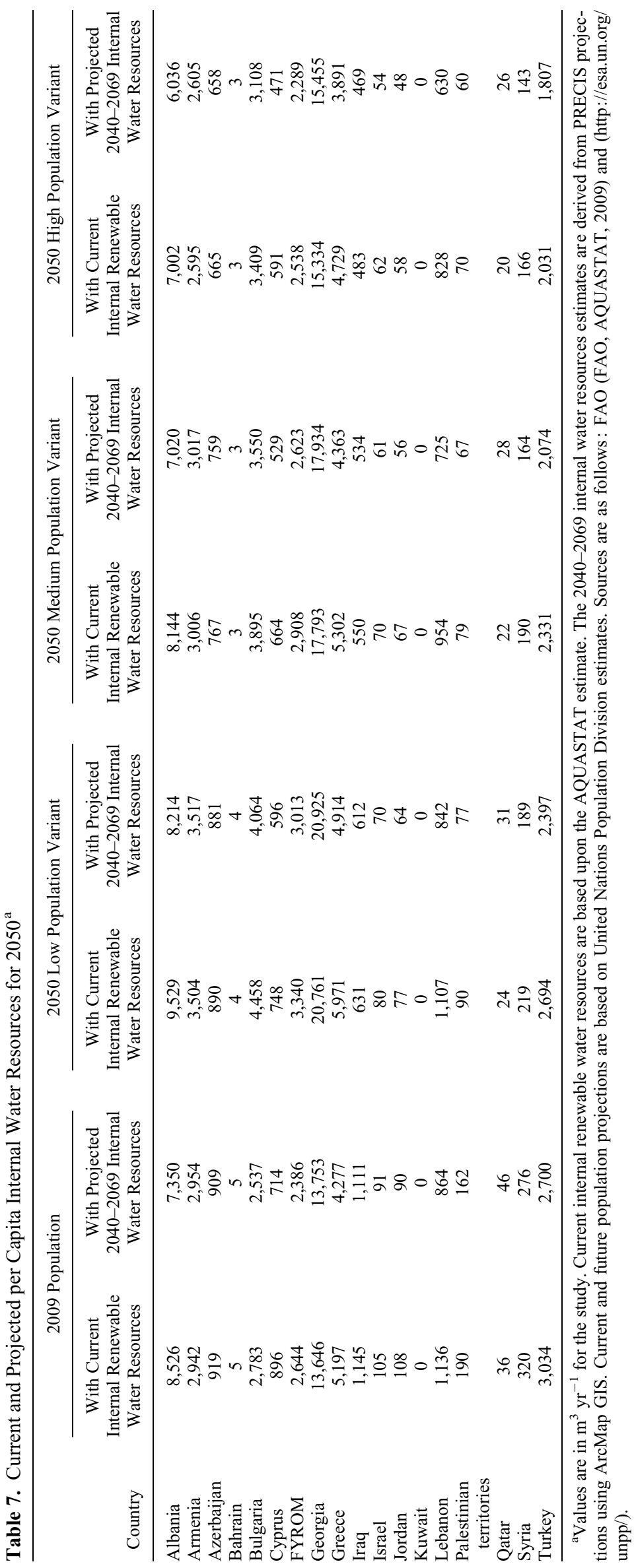


environmental flows, the quality of the environment is reduced, but this may or may not translate into direct economic costs. Where declining water resources, however, are replaced through increased desalination, an economic cost can be estimated since the current minimum cost of desalinating seawater is known. Desalination costs have steadily declined over the last few decades, with recent desalination contracts providing desalinated seawater at a cost as low as $\$ 0.53 \mathrm{~m}^{-3}$ in the case of the Ashkelon plant in Israel and $\$ 0.45 \mathrm{~m}^{-3}$ in the case of Singapore [Gleick et al., 2006]. However, desalination based on fossil fuels, as is currently the norm in the region, will contribute, in turn, to global warming.

[34] The volume of internal water resources across the study countries is modeled to decline from $464 \mathrm{~km}^{3} \mathrm{yr}^{-1}$ in $1961-1990$ to $419 \mathrm{~km}^{3} \mathrm{yr}^{-1}$ in 2040-2069, a loss of 45 $\mathrm{km}^{3} \mathrm{yr}^{-1}$, and to $412 \mathrm{~km}^{3} \mathrm{yr}^{-1}$ in 2070-2099, a loss of 52 $\mathrm{km}^{3} \mathrm{yr}^{-1}$. At a price of $\$ 0.50 \mathrm{~m}^{-3}$, the cost of replacing the lost volume of internal water resources through desalination would be $\$ 22.5 \times 10^{9} \mathrm{yr}^{-1}$ in the $2040-2069$ period and $\$ 26 \times 10^{9} \mathrm{yr}^{-1}$ in the 2070-2099 period when evaluated in current U.S. dollars. This compares to total gross domestic product (GDP) across the study countries in 2008, which was in excess of $\$ 1736$ billion [United Nations Development Programme, 2010]. Obviously, it is unlikely that decreases in internal water resources would be fully replaced by desalination in each country, but conversely, desalinated seawater may require expensive pumping inland, which adds to the cost, and there would be significant environmental impacts resulting from such large-scale desalination. Nonetheless, this provides a very crude indication of how costly changes in available water resources may be in absolute terms and in relation to the overall size of the region's economy.

\subsection{Impacts of Climate Change and Possible Adaptation Measures}

[35] There is a growing body of literature on possible adaptation measures to deal with climate change, including research that has looked specifically at adaptation measures relating to water resources [Fung et al., 2011; O'Neill and Dobrowolski, 2011; Sowers et al., 2011; Warren, 2011; Ziervogel et al., 2010]. Population projections for $2050 \mathrm{com}-$ bined with the projected 2040-2069 internal water resources provide an indication of possible per capita water resources for 2050. As outlined in the country analyses in sections 4.6.1-4.6.18, countries that are already water scarce or severely water scarce all suffer reductions in their per capita internal water resources when the medium-variant population projection for 2050 is combined with the modeled change in water resources. Given the transboundary nature of some key water resources in the region, international cooperation will be required in some river basins, some of which are partially managed through international treaties [Drieschova et al., 2009]. The Jordan River basin is an example of such a river basin. As the analyses below are based on annual precipitation values, adaptation measures required specifically to deal with temporal variability and changes in the frequency of extreme events are not considered.

\subsubsection{Albania}

[36] According to the analysis of the PRECIS model results, Albania's water resources will decline by $14 \%$.
With its population not expected to grow significantly and being generously endowed with water relative to its population, Albania should not experience significant socioeconomic impacts due to climate change reducing water availability.

\subsubsection{Armenia}

[37] The PRECIS model results suggest that precipitation and water resources will increase very slightly by the middle of the century and then decline slightly by the end of the century relative to 1961-1990 levels, but the change in precipitation in both cases will be less than $1 \%$. With Armenia's population not expected to change significantly, per capita water resources will not change significantly either. Thus, in terms of its effect on water resources, climate change is not expected to require significant adaptation in Armenia.

\subsubsection{Azerbaijan}

[38] By midcentury, PRECIS suggests that precipitation in Azerbaijan is expected to have declined by $1.1 \%$, with a further $0.1 \%$ decline over the remainder of the century; thus, the effects of climate change on water resources will be negligible. Azerbaijan is expected to have some population growth over the coming decades, resulting in water resources per capita declining from around $919 \mathrm{~m}^{3}$ at present to around $759 \mathrm{~m}^{3}$ by midcentury. With $25 \%$ of its economically active population working in agriculture [FAO, 2006], socioeconomic change will be required as its agricultural sector shrinks because of growing water scarcity due primarily to population growth and economic growth.

\subsubsection{Bahrain}

[39] With extremely low precipitation rates and relatively high evapotranspiration, the PRECIS modeling suggests that Bahrain's extremely meager water resources will remain extremely limited. Thus, desalination will remain the primary source of fresh water in Bahrain, supporting an economy dependent upon services, industry, and mining.

\subsubsection{Bulgaria}

[40] The PRECIS projections suggest that Bulgaria will experience a $9 \%$ decrease in precipitation and water resources by midcentury and a $13 \%$ decrease by the end of the century. However, with Bulgaria's population projected to have declined even more significantly by the middle of the century, per capita water resources are expected to increase. Demographic change is likely to require more adaptation of its agricultural sector (and the economy more generally) than climate change.

\subsubsection{Cyprus}

[41] The PRECIS projections results suggest that precipitation in Cyprus will decrease by $20 \%$ by midcentury. Some of this decrease will be reversed by the end of the century, with precipitation in 2070-2099 decreasing by $17 \%$ relative to 1961-1990. Coupled with population growth, per capita water resources by midcentury are expected to be only slightly in excess of half their current levels. Such a change will severely impact upon both Cyprus' agricultural sector and also its urban water supply systems. Agriculture will have to rely increasingly on treated wastewater, while desalination is expected to supply an increasing proportion of the urban water supply.

\subsubsection{FYROM}

[42] FYROM is expected to face a $10 \%$ decrease in precipitation by midcentury, with the decrease reaching $14 \%$ 
by the end of the century. With population projected to decline by a similar amount as precipitation and water resources, there is no need for FYROM to anticipate any significant change in per capita water resources by midcentury. Demographic change is likely to bring greater change to its economy than climate change.

\subsubsection{Georgia}

[43] PRECIS suggests that Georgia will experience modest increases in precipitation and water resources by midcentury, which will further increase modestly by the end of the century. Coupled with the significant decline in population that is expected, Georgia's per capita water resources, which are already the greatest of the study countries, will increase significantly. Thus, like some of the other European countries of the study region, demographic change will likely bring far greater change to its water resources and economy than climate change, and the country may have some scope to develop more water-intensive industries to help compensate for the water resources declines elsewhere.

\subsubsection{Greece}

[44] Greece is expected to have an $18 \%$ precipitation decrease by midcentury, and $22 \%$ by the end of the century. With modest population decline expected, Greece's per capita water resources are expected to decline somewhat by midcentury but still remain high compared to the majority of the study countries. Thus, climate change is likely to necessitate modest changes to Greece's water resources management.

\subsubsection{Iraq}

[45] Iraq is expected to have a $3 \%$ decrease in precipitation by midcentury and a $5 \%$ decrease by the end of the century. In addition, by midcentury the discharge of the Tigris-Euphrates is expected to have declined by $10 \%$, although no further decline is predicted over the remainder of the century. With Iraq being the downstream riparian nation of the river basin, it is likely to suffer a disproportionate share of this decline in discharge as the upper riparians try to limit the impact of the decline by taking an increasing share of the water resources. On top of the significant declines in internal and total water resources, Iraq has a very fast growing population, which is expected to double by midcentury. This will produce a greater change in per capita water resource availability than climate change. Thus, Iraq will probably change from being water stressed to being water scarce, a change that is likely to impact severely on its large irrigated agricultural sector and require significant adaptation. That the effects of population growth are likely to be far more significant than climate change for Iraq is similar to the conclusion reached by Conway [2005], who on the basis of a review of several studies relating climate change and the Nile River, concluded that climate change impacts in Egypt were likely relatively minor in relation to nonclimate changes, such as population growth and socioeconomic development.

\subsubsection{Israel}

[46] The PRECIS results suggest that Israel will experience a decrease of $13 \%$ in precipitation by midcentury and $19 \%$ by the end of the century. However, the discharge of the Jordan River, one of Israel's major water sources, is expected to decrease even more, i.e., $22 \%$ by midcentury and $30 \%$ by the end of the century; thus, the total water resources of the country will be severely affected by climate change. With population expected to increase significantly, per capita internal water resources are expected to decline to a very low level, only $61 \mathrm{~m}^{3}$ per capita under the medium population projection by midcentury. This means that the existing trend of a declining agricultural sector that is increasingly reliant on treated wastewater as its water source will likely continue as the country relies more and more on desalination to meet its water needs and economically relies on its industrial and service based economy rather than its agricultural sector.

\subsubsection{Jordan}

[47] Precipitation is modeled to decrease by $17 \%$ by midcentury and $21 \%$ by the end of the century. The discharge of the Jordan River system, the country of Jordan's primary water source, is projected to decrease by $22 \%$ by midcentury and $30 \%$ by the end of the century. With significant population growth also forecasted, Jordan's per capita water resources are projected to shrink significantly from an already very low level. Under the medium population projection of the United Nations, annual per capita water resources may only be $56 \mathrm{~m}^{3}$ by midcentury and still declining. At this level, Jordan's water resources will only be slightly above the minimum water requirement for social and economic development that would allow the country to provide its citizens with a high quality of life, and given the variability of precipitation in the region, in some years, even the minimum water requirement will not be available. Although some of the water Jordan takes from the Jordan River basin is secured by international treaties, such treaties may have to be renegotiated if precipitation in the basin declines radically.

[48] Unlike most of the other study countries, Jordan's options for dealing with its increasing water scarcity are limited as it lacks a long coastline adjacent to its major population centers. The vast majority of Jordan's population lives in the Amman region in central northern Jordan at an altitude of 600-900 m above sea level, with the country's only coastline on the Red Sea a few hundred kilometers away. This makes desalination a very costly option for the country and suggests that it will need to cooperate with its neighbors if it is to develop a more cost-effective solution for providing additional water supplies while at the same time maximizing water use efficiency and wastewater reuse.

\subsubsection{Kuwait}

[49] Kuwait currently has essentially no internal water resources and is thus dependent on desalination to meet its freshwater needs. This situation is not expected to change with climate change.

\subsubsection{Lebanon}

[50] Precipitation is expected to decrease by $24 \%$ by midcentury and decrease by $31 \%$ by the end of the century. With Lebanon's population also projected to increase, per capita internal water resources will decrease from around $1136 \mathrm{~m}^{3}$ today to around $725 \mathrm{~m}^{3}$ by the middle of the century. This decrease will be due fairly equally to both population growth and climate change. Such a decrease will create some water supply challenges, particularly during drought years, but it still leaves Lebanon with significantly more per capita water resources than its neighbors. It will take Lebanon's per capita water resources below the 
current level of Cyprus but well above the current level of Israel.

\subsubsection{Palestinian Territories}

[51] In the Palestinian territories, precipitation is expected to decrease by $15 \%$ by midcentury and $23 \%$ by the end of the century. Simultaneously, the population of the Palestinian territories is projected to more than double by midcentury; thus, any change in per capita water resources availability due to climate change is likely to be minor compared to the change due to population growth. Per capita internal water resources may only be $67 \mathrm{~m}^{3}$ by midcentury compared to $190 \mathrm{~m}^{3}$ now. In the Gaza Strip, large-scale desalination or water imports will be the only options for meeting the population's water needs in what will increasingly be an urban economy. In the West Bank, greater use of the aquifers shared with Israel and the Jordan River system will be required in order to meet basic water needs. However, with the discharge of the Jordan projected to decrease by $22 \%$ by midcentury and $30 \%$ by the end of the century, the scope for gaining a share of this river as a downstream riparian will be limited. This means that like Gaza, the West Bank's economy will have to become nearly entirely industrial and service based, with little agriculture, if economic development needs are to be met in the context of severe water scarcity.

\subsubsection{Qatar}

[52] Qatar currently has extremely limited available renewable freshwater resources and is thus largely dependent on desalination to meet its freshwater needs. This situation is not expected to change with climate change even though PRECIS predicts a $28 \%$ increase in precipitation in Qatar by midcentury and a $55 \%$ increase by the end of the century, in part because population is expected to increase by a greater amount, which will ensure no increase in per capita water resources.

\subsubsection{Syria}

[53] PRECIS projections suggest an average precipitation decline of $14 \%$ by midcentury and $16 \%$ by the end of the century for Syria. With population anticipated to have increased very substantially, annual per capita internal water resources will nearly halve by midcentury to only $164 \mathrm{~m}^{3}$. Being a riparian nation on both the Jordan River and also the Tigris-Euphrates river basin, it will also be affected by changes within these catchments, with both rivers expecting a significant decrease in discharges. While it is an upper riparian in the Jordan and thus may be able to compensate for reduced precipitation by taking a larger share of the Jordan's waters, in the case of the TigrisEuphrates, which is a far larger and more significant water resource, it is a midriparian and thus may suffer reduced water availability if Turkey compensates for its own reduced water availability by taking an increasing share of the Tigris-Euphrates waters.

[54] In Syria, $88 \%$ of water withdrawals are currently for agriculture, and $25 \%$ of the agricultural land is irrigated [FAO, 2009]. Approximately $25 \%$ of the economically active workers are employed in agriculture, meaning that the socioeconomic implications of climate change could be severe for this segment of the society and could possibly lead to cascade effects elsewhere in the economy. Thus, the more rapidly that the Syrian government can develop its industrial and service based economy, the easier such a transition will be.

\subsubsection{Turkey}

[55] Turkey has by far the largest rural population of the study area, with $43 \%$ of its economically active population, nearly 15 million people, working in agriculture. Its precipitation and water resources were projected to suffer a modest decline of $11 \%$ by midcentury and $12 \%$ by the end of the century. While the decline in water resources that Turkey faces is slightly less than Syria and water resources as a whole for the country remain relatively plentiful, Turkey is still facing having its per capita water resources decrease by nearly one third by midcentury. Turkey's agricultural sector will therefore be forced to become more water efficient and will, despite this increased efficiency, probably still decline as a source of employment. In spite of this decline, Turkey is likely to remain a major net agricultural exporter as its large land area, large rural population, and relatively large water resources will allow it to export virtual water to its water-scarce regional environment.

\section{Discussion and Conclusions}

[56] The PRECIS projections for the 21st century, based on the IPCC SRES scenario A1B, suggest that precipitation in the countries of the EMME region will decline by an average of about $10 \%$, with a great diversity among individual countries. These are highly significant changes, which will require considerable adjustments of water resource management in many countries and associated infrastructural changes that in some cases, will necessitate decades to plan and implement.

[57] When the PRECIS modeling results for the recent past (1961-1990), however, are compared to the AQUASTAT and CRU data sets, the average difference between the annual precipitation estimate of PRECIS and that of AQUASTAT is $27 \%$. The PRECIS projections fall in line with an ensemble of 16 statistically downscaled GCMs and could be considered useful for showing the direction of trends and providing some indication of the magnitude of the trend, but uncertainties of the modeling process are such that the extent of the decline cannot be reliably and precisely quantified. The uncertainty is magnified further when considering that the modeling is based upon a single IPCC SRES scenario, whose likelihood of being realized is itself uncertain.

[58] According to Giorgi and Lionello [2008], the two main sources of uncertainty in precipitation projections in the eastern Mediterranean are uncertainties in GCM boundary conditions and internal RCM physics and dynamics. In addition to these, in spite of the relatively high resolution of the PRECIS RCM compared to global climate models, it is still too coarse for accurate precipitation estimation on a country level because of its inability to capture finer topographical features at the subcell level and insufficient handling of the land-sea interface. Since precipitation is highly variable on both the spatial and temporal scales, it is even more difficult to model changes, especially for small countries.

[59] The modeling results need to be taken in their wider societal context. Climate is just one of the many factors that will change over the coming century if history is any guide. Despite minimal climate change occurring during the 20th century, the world in the year 2000 was nearly unrecognizable from the world of 1910 . To put the changes 
in water resources that have been envisaged into context, take the example of Jordan. In the 1930s, Jordan had a population of about 300,000 people [Casto and Dotson, 1938]. The population of the country subsequently rose dramatically, partly through a high natural growth rate but also through influxes of refugees: 450,000 immigrants from Palestine in 1948-1950, 400,000 immigrants from the West Bank in 1967, and 300,000 Jordanian nationals from the Gulf states following the 1991 Gulf War [Hassan, 2004], with the recent conflict in Iraq bringing more than 500,000 Iraqi refugees to Jordan during the last 5 years [United Nations High Commission for Refugees, 2010]. While some of the change in population due to natural growth may have been possible to predict in advance using demographic models, predicting the sudden and dramatic changes in population due to immigration, such as the approximate doubling of the population in 1948-1950 due to the influxes of refugee immigrants, would not have been possible. However, as a result of these changes, water resources per capita have decreased from approximately $2350 \mathrm{~m}^{3}$ per capita per year in the $1930 \mathrm{~s}$ to $111 \mathrm{~m}^{3}$ per capita per year today. Considering the scale of the demographic change that occurred in this time period, any shifts in per capita water resources availability due to climate were insignificant in comparison.

[60] If the extent of the economic and technological development that occurred during the 20th century is any guide, then the economic and technological change that will occur during the 21 st century will also transform water resources management in the study countries far more than climate change will. While credible economic data stretching back a century are limited, according to the economic historian A. Maddison (see http://www.ggdc.net/MADDISON/oriindex.htm), GDP in Jordan grew from \$348 million in 1913 to $\$ 28,946$ million in 2006 (measured in constant 1990 U.S. dollars), an 83-fold increase. Elsewhere, the transformation was similarly great. GDP increased in Turkey from $\$ 18,195$ million in 1913 to $\$ 568,953$ million in 2006 and in Greece from $\$ 8,635$ million in 1913 to $\$ 168,106$ in 2006. Simultaneously, the real cost of water supply technologies, and specifically desalination, has fallen significantly over the past century. The average unit of cost of desalination has fallen from around $\$ 6.00 \mathrm{~m}^{-3}$ in 1960 , about the time when the first large-scale commercial desalination plants started operating, to around $\$ 1.0 \mathrm{~m}^{-3}$ today [Zhou and Tol, 2005], with costs as low as $\$ 0.45$ achieved in some locations today.

[61] While political and social changes cannot generally be modeled over century-long time scales, climate change can be modeled, and although the accuracy of the results is less than desired, the direction and magnitude of the changes identified are relatively certain. Thus, in a future that is full of technological, political, social, and economic uncertainty, climate change is a relative certainty that can be considered and planned for by policy makers. This is useful given that major water resources infrastructure can require very long lead times. For example, although the water transfer scheme from Lake Tiberius to Israel's coastal plain, the National Water Carrier, was first proposed before Israel as a country was established, the National Water Carrier only became operational in the mid-1960s.
[62] Broadly speaking, analysis of the PRECIS projections for the EMME region in terms of the effects of climate change suggests that water resources will not change particularly significantly in southeastern Europe, where water resources are presently relatively plentiful and population growth is small or even negative. However, in much of the Middle East, including those areas where agriculture is still highly significant, despite relatively limited water resources availability, climate change coupled with population growth is likely to considerably reduce both total water resources and, particularly, per capita water resources. This will inevitably result in major social, economic, and environmental change in the region, bringing about urbanization and requiring significant development of the industrial and service based economies of these countries. Thus, significant adaptation taking place over decades will be required.

[63] Acknowledgments. We thank the PRECIS team of the UK Met Office Hadley Centre for provision of (and help with) the PRECIS software. E. Xoplaki acknowledges support from the EU/FP6 integrated project CIRCE (NO036961) and from the EU/FP7 project ACQWA (NO212250).

\section{References}

Allan, J. A. (2001), The Middle East Water Question: Hydropolitics and the Global Economy, 387 pp., I. B. Tauris, London.

Ben-Zvi, A., and A. Givati (2008), Comment on "First super-high-resolution model projection that the ancient "Fertile Crescent" will disappear in this century" by Akio Kitoh, Akiyo Yatagai and Pinhas Alpert, Hydrol. Res. Lett., 2, 45.

Casto, E. R., and O. W. Dotson (1938), Economic geography of trans-Jordan, Econ. Geogr., 14(2), 121-130.

Chapagain, A. K., and A. Y. Hoekstra (2004a), Water Footprints of Nations, vol. 2, Appendices, Value Water Res. Rep. Ser. 16, Inst. for Water Educ., U. N. Educ., Sci. and Cultural Organ., Delft, Netherlands.

Chapagain, A. K., and A. Y. Hoekstra (2004b), Water Footprints of Nations, vol. 1, Main Report, Value Water Res. Rep. Ser. 16, Inst. for Water Educ., U. N. Educ., Sci. and Cultural Organ., Delft, Netherlands.

Chenoweth, J. (2008), Minimum water requirement for social and economic development, Desalination, 229, 245-256.

Chiew, F. H. S. (2006), Estimation of rainfall elasticity of streamflow in Australia, Hydrol. Sci. J., 51(4), 613-625.

Conway, D. (2005), From headwater tributaries to international river: Observing and adapting to climate variability and change in the Nile basin, Global Environ. Change, 15(2), 99-114.

Dorn, H. F. (1950), Pitfalls in population forecasts and projections, J. Am. Stat. Assoc., 45(251), 311-334.

Drieschova, A., et al. (2009), Adapting to Climate Change: Thresholds, Values, Governance, edited by W. N. Adger et al., Cambridge Univ. Press, Cambridge, U. K.

Falkenmark, M. (1992), Water scarcity and population growth: A spiralling risk, Ecodecision, 6, 21-23.

Falkenmark, M. (1995), Land-water linkages: A synopsis, in Land and Water Integration and River Basin Management, FAO Land Water Bull., $1,15-16$.

Foley, A. M. (2010), Uncertainty in regional climate modelling: A review, Prog. Phys. Geogr., 34(5), 647-670.

Food and Agriculture Organization (FAO) (2006), FAO Statistical Yearbook 2005-2006, Rome.

Food and Agriculture Organization (FAO) (2009), Irrigation in the Middle East Region in Figures: AQUASTAT Survey-2008, FAO Water Rep. 34, edited by K. Frenken, Rome.

Fung, F., A. Lopez, and M. New (2011), Water availability in $+2{ }^{\circ} \mathrm{C}$ and $+4{ }^{\circ} \mathrm{C}$ worlds, Philos. Trans. R. Soc. A, 369(1934), 99-116.

Giorgi, F., and P. Lionello (2008), Climate change projections for the Mediterranean region, Global Planet. Change, 63(2-3), 90-104.

Gleick, P. H., H. Cooley, and G. Wolff (2006), With a grain of salt: An update on seawater desalination, in The World's Water, 2006-2007: The 
Biennial Report on Freshwater Resources, edited by P. H. Gleick, pp. 51-90, Island Press, Washington, D. C.

Goldstein, J. R., and G. Stecklov (2002), Long-range population projections made simple, Popul. Dev. Rev., 28(1), 121-141.

Hassan, F. M. A. (2004), Jordan: Supporting Stable Development in a Challenging Region, World Bank, Washington, D. C.

Hemming, D., et al. (2010), How uncertain are climate model projections of water availability indicators across the Middle East?, Philos. Trans. R. Soc. A, 368(1931), 5117-5135.

Intergovernmental Panel on Climate Change (IPCC) (2000), Special Report on Emissions Scenarios, edited by N. Nakicenovic and R. Swart, Cambridge Univ. Press, New York.

Intergovernmental Panel on Climate Change (IPCC) (2007), Climate Change 2007: Synthesis Report, Contribution of Working Groups I, II and III to the Fourth Assessment Report of the Intergovernmental Panel on Climate Change, edited by Core Writing Team, R. K. Pachauri, and A. Reisinger, Geneva, Switzerland.

Jones, C., et al. (2008), Hydrologic impacts of engineering projects on the Tigris-Euphrates system and its marshlands, J. Hydrol., 353(1-2), 59-75.

Jones, R., et al. (2004), Generating high resolution climate change scenarios using PRECIS, 40 pp., Met Off. Hadley Cent., Exeter, U. K.

Kitoh, A., A. Yatagai, and P. Alpert (2008), First super-high-resolution model projection that the ancient "Fertile Crescent" will disappear in this century, Hydrol. Res. Lett., 2, 1-4.

Krichak, S. O., et al. (2007), The surface climatology of the eastern Mediterranean region obtained in a three-member ensemble climate change simulation experiment, Adv. Geosci., 12, 67-80.

Kunstmann, H., et al. (2009), P3: Regional climate scenarios, in GLOWA Jordan River: An Integrated Approach to Sustainable Management of Water Resources Under Global Change, Phase II Final Report, pp. 55-72.

Murakami, M. (1995), Managing Water for Peace in the Middle East: Alternative Strategies, U. N. Univ. Press, Tokyo.

New, M., et al. (2002), A high-resolution data set of surface climate over global land areas, Clim. Res., 21, 1-25.

O’Neill, M. P., and J. P. Dobrowolski (2011), Water and agriculture in a changing climate, HortScience, 46(2), 155-157.

Önol, B., and F. H. M. Semazzi (2009), Regionalization of climate change simulations over the eastern Mediterranean, J. Clim., 22(8), 1944-1961.
Oroud, I. M. (2010), The impacts of climate change on water resources in Jordan, in Climatic Changes and Water Resources in the Middle East and North Africa, edited by F. Zereini and H. Hötzl, pp. 109-123, Springer, Berlin.

Plan Bleu (2009), State of the Environment and Development in the Mediterranean-2009, Mediter. Action Plan, U. N. Environ. Programme, Athens. Samuels, R., et al. (2010), Climate change impacts on Jordan River flow: Downscaling application from a regional climate model, J. Hydrometeorol., 11(4), 860-879.

Sowers, J., A. Vengosh, and E. Weinthal (2011), Climate change, water resources, and the politics of adaptation in the Middle East and North Africa, Clim. Change, 104(3-4), 599-627.

United Nations Development Programme (2010), Human Development Report 2010, Oxford Univ. Press, New York.

United Nations High Commission for Refugees (2010), 2010 UNHCR country operations profile-Jordan, report, Geneva, Switzerland.

United Nations Population Division (2009), World population prospects, the 2008 revision, report, New York.

Warren, R. (2011), The role of interactions in a world implementing adaptation and mitigation solutions to climate change, Philos. Trans. R. Soc. A, 369(1934), 217-241.

Wilby, R. L. (2010), Evaluating climate model outputs for hydrological applications, Hydrol. Sci. J., 55(7), 1090-1093.

Wood, W. A., et al. (2004), Hydrologic implications of dynamical and statistical approaches to downscaling climate model outputs, Clim. Change, 62, 189-216.

Zhou, Y., and R. S. J. Tol (2005), Evaluating the costs of desalination and water transport, Water Resour. Res., 41, W03003, doi:10.1029/ 2004WR003749.

Ziervogel, G., et al. (2010), Using climate information for supporting climate change adaptation in water resource management in South Africa, Clim. Change, 103(3-4), 537-554.

A. Bruggeman, P. Hadjinicolaou, M. A. Lange, J. Lelieveld, Z. Levin, and E. Xoplaki, Energy, Environment and Water Research Center, Cyprus Institute, 20 Constantinou Kavafi St., Nicosia 2121, Cyprus.

J. Chenoweth and M. Hadjikakou, Centre for Environmental Strategy, University of Surrey, Guildford GU2 7XH, UK. (j.chenoweth@surrey. ac.uk) 